\title{
THE STATUS OF INTERNATIONAL LAW IN THE MALAYSIAN MUNICIPAL LEGAL SYSTEM: CREEPING MONISM IN LEGAL DISCOURSE?
}

\author{
Farid Sufian Shuaib*
}

\begin{abstract}
This article revisits the status of international law in the Malaysian municipal legal system and considers whether monism is the doctrine or the preferred doctrine in relation to the proper place of international law in Malaysia. This revisit is necessary because of the tendency in some legal writings and legal opinions to take a cavalier approach in using international instruments to dictate the content of municipal law. While observing the ascendancy of international institutions and instruments in determining international and national obligations, it is necessary to take stock of things to maintain a balance between being sovereign and being a member of the global neighbourhood.
\end{abstract}

Assistant Professor, Ahmad Ibrahim Kulliyyah of Laws, International Islamic University Malaysia. He may be contacted at farid@iium.edu.my. The author would like to thank Dr Mohd Hisham Mohd Kamal and an anonymous referee for their comments to an earlier draft of this article. Responsibility for any error remains with the author. 


\section{INTRODUCTION}

With the onslaught of globalisation and the ever interconnected world that we are in today, international law becomes the flavour of the month. ${ }^{1}$ The interest is heightened by Malaysia's territorial disputes with Singapore and Indonesia. Discussion of any legal issues-particularly relating to human rights-will invite some discussants to broach international instruments; be it the Convention on the Elimination of All Forms of Discrimination against Women (CEDAW) or the more generic instrument such as the Universal Declaration of Human Rights 1948. The interest in international law is reflected also in the curriculum development of law schools. So far as our query permits, all law schools at public institutions of higher learning have public international law as a compulsory subject. $^{2}$

Nevertheless, in the context of a municipal legal system, this should not detract from the fact that the status of international law needs to be understood within the context of the municipal legal system. Provision from international instruments cannot by itself become law for the municipal legal system. The doctrine of monism where international law reigns supreme even in the municipal sphere is antagonistic to municipal integrity of domestic law and domestic legal institutions. But this does not stop some people from reciting international instruments like mantra from sacred texts.

What is referred to as creeping monism is the cavalier approach in legal discourse in using international instruments to dictate municipal law without highlighting the fact that it is necessary to have implementing or transforming legislation in the first place. The phrase "legal discourse" is purposely used to refer to discourse through legal writings and legal opinions which is not necessarily borne out from judgment of the courts. ${ }^{3}$

$1 \quad$ On globalisation, see for instance Robbie T Robertson, The Three Waves of Globalization: A History of a Developing Global Consciousness, Nova Scotia: Fernwood Publishing and Zed Books, 2003.

2 I would like to thank Muhammad Nizam Awang of the Faculty of Syariah and Law, Islamic Science University of Malaysia for his assistance in providing this information.

3 For some legal discourse relating to international instruments, see Dato’ Param Cumaraswamy, "Parliamentary Action to Ensure the 
Courts in other jurisdictions may have developed "interpretive incorporation techniques" to entrench treaty provisions into domestic law. ${ }^{4}$ This generally has yet to occur in Malaysia. The purpose of this article is to revisit the status of international law and to consider whether monism has a place in the Malaysian legal system as seem to be suggested in some of the legal discourse.

Be that as it may, international law is important to make sense of our interdependent and multivalent world. Although we are not yet a "global village," we are indeed a global neighbourhood. ${ }^{5}$ Thus, one is illadvised to dismiss the importance of international law.

\section{THE QUESTION OF INTERNATIONAL LAW BEING "LAW"}

Before going further, it is helpful to briefly consider the question of international law being "law." This issue needs to be put out of the way so that the basis of the foregoing discussion would be on the position of international law as "law." International law is traditionally defined as "the body of rules which are legally binding on States in their intercourse with each other." ${ }^{6}$ Since the $20^{\text {th }}$ century, international persons include international organisations.

Some question the status of international law being "law." Under the Austinian view, international law lacks a sovereign political authority above States.

Independence and Good Administration of Justice” (2002) 31:2 INSAF 82; Ramdas Tikamdas, "National Security and Constitutional Rights: The Internal Security Act 1960” (2003) 32:1 INSAF 75; Malik Imtiaz Ahmed Bin Ghulam Sarwar, "Traditional Practices and Contemporary International Rights” (2003) 32:3 INSAF 7; Edmund Bon, “Advocating International Law” (2004) 33:2 INSAF 75.

$4 \quad$ See Melissa A Waters, "Creeping Monism: The Judicial Trend toward Interpretive Incorporation of Human Rights Treaties” (2007) 107 Colum L Rev 628.

5 Peter De Cruz, Comparative Law in a Changing World, $2^{\text {nd }}$ Ed., London: Cavendish, 1999, at 29.

$6 \quad$ LFL Oppenheim, Oppenheim's International Law, Vol. 1, 9 $9^{\text {th }}$ Ed., London: Longman, 1996. 
However, the Austinian view has been discredited. Law does not necessarily flow from the command of a sovereign. It may evolve from practices which are regarded as binding by relevant parties. Thus, recognition by States and political continuity of its related institution satisfy this requirement. This fits the description of international law as a "system of customary law upon which has been erected a superstructure of conventional or treaty-made law." 7 Such definition may be regarded outdated with the emergence of new private actors such as in the form of non-governmental organizations (NGOs), in the work of international institutions and in the norm and treaty formation process. This aspect of international law will be considered briefly below.

\section{SOURCES OF INTERNATIONAL LAW}

It is necessary to make, before considering the central theme of this article, a brief survey of sources of international law. Since international law is sometime regarded as still a highly specialised subject, it is beneficial as background information, to consider a principal aspect of the law. Study of international law is not only about sources of international law. A cursory reference to international law textbooks will reveal wide ranging topics such as statehood, territorial sovereignty, law of the sea, protection of environment, international dispute settlement and international organisations. However, in the context of the present work, we need not delve into these topics.

The sources of international law are international conventions, international custom as evidence of a general practice, general principles of law recognised by civilised nations, and judicial decisions and recognised writings of jurists. This list of sources of international law is used by the International Court of Justice, a principal organ of the United Nations. ${ }^{8} \quad$ The list is regarded as a complete statement of sources of international law. ${ }^{9}$

$7 \quad$ L Harris, Legal Philosophies, London: Butterworths, 1980, at 588.

$8 \quad$ Article 38 of the Statute of the International Court of Justice.

$9 \quad$ Ian Brownlie, Principles of Public International Law, Oxford: Clarendon Press, 1998, at 3; LFL Oppenheim, Oppenheim's International Law, Vol. 1, $9^{\text {th }}$ Ed., London: Longman, 1996. 
International conventions are considered the most important source because the conventions express mutual obligations among parties. Conventions can be bilateral or multilateral. Treaties do not necessarily constitute international law since the treaties merely evince agreed obligations among parties. However, practices of States in accordance with treaty obligations may transform those obligations into accepted practices among nations. Treaties also may reduce into writing customary rules of international law. An example of a treaty is the Convention on the Elimination of All Forms of Discrimination against Women (CEDAW).

The second source refers to customary rules of international law, namely a general recognition among States of obligatory practices. ${ }^{10}$ Customs and usages are different because usages only refer to general practices that do not amount to obligations such as exemptions of diplomatic vehicles from parking prohibition. ${ }^{11}$ However, the practice of giving immunity to the Head of State of a foreign State is considered a custom since it is observed among States.

The third source is general principles of law recognised by civilised States. This refers to municipal jurisprudence that is applicable to States relations. ${ }^{12}$ In this way international tribunals such as the International Court of Justice, could borrow (not necessarily follow) for instance evidentiary and procedural rules from municipal jurisprudence to regulate disputes among States. International tribunals may make use of municipal private law in developing, through analogies, international law. The International Court of Justice has construed the requirement to file "as soon as possible" an application to intervene made by the Philippines in the dispute of Pulau Sipadan between Malaysia and Indonesia by referring to the concept of "sound administration of justice." ${ }^{13}$ Although the Court

$10 \quad$ For examples of customary law see for instance the law on treaties in Case Concerning Sovereignty over Pulau Ligitan and Pulau Sipadan (Indonesia/Malaysia) (2002) ICJ 625, at 645.

11 Ian Brownlie, Principles of Public International Law, Oxford: Clarendon Press, 1998, at 5.

12 LFL Oppenheim, Oppenheim's International Law, Vol. 1, 9 ${ }^{\text {th }}$ Ed., London: Longman, 1996. For other views, see Ian Brownlie, Principles of Public International Law, Oxford: Clarendon Press, 1998, at 15-16. 13 Case Concerning Sovereignty over Pulau Ligitan and Pulau Sipadan (Indonesia/Malaysia) (2001) ICJ 575, at 585. 
did not refer specifically to any State law, the procedural requirement is certainly analogous to municipal administration of justice.

The fourth source of law is recognised writings of jurists. Writing of jurists may form evidence of the law-it records what in the finding of the jurists to be the international law. ${ }^{14}$ Nevertheless, jurists may do more than that. Writing of jurists may influence the development of international law itself. Obviously individual writers' writings reflect their own world view and conception of the world. Nevertheless, judgments of international tribunals are replete with references to writings of jurists. ${ }^{15}$ However, their role though important, is less so today. ${ }^{16}$

The sources of international law, as above, taken from an international instrument ${ }^{17}$ fail to consider the gaining prominence of private actors-such as nongovernmental organizations (NGOs), in the work of international institutions and in the norm and treaty formation, design and compliance processes. The rise of these actors means the rise of nonconsensual international law. ${ }^{18}$ This is opposite to the basis of law making in treaties, for instance. ${ }^{19}$ This can be seen largely in areas of transnational terrorism and human rights. ${ }^{20}$

\section{RELATIONSHIP BETWEEN MUNICIPAL LAW AND INTERNATIONAL LAW}

In the context of a municipal legal system, among the important issues concerning international law is its relation with the municipal legal system. The relation between the law of one country (municipal law)

\footnotetext{
$14 \quad$ Ian Brownlie, Principles of Public International Law, Oxford: Clarendon Press, 1998, at 24.

15 See for instance South West Africa case (1950) ICJ Reports 146.

16 DJ Harris, Cases and Material on International Law, $5^{\text {th }}$ Ed., London: Sweet \& Maxwell, 1998, at 56-57.

17 Article 38 of the Statute of the International Court of Justice.

18 See for instance the elaborate compliance audit processes under CEDAW.

19 See Christian Tomuschat, "Obligations Arising for States Without or Against Their Will” (1993) 241-IV Rec. des Cours 195. (2008) U Ill L Rev 71.
} 
and international law is a vexing question touching issues of State sovereignty and shared values among nations. Issues regarding the position of the Universal Declaration of Human Rights in municipal law for instance, keep surfacing when Malaysians discuss about human rights. The first question that may be asked is whether such an international instrument changes the Malaysian law? Alternatively, should the Malaysian court consider itself bound to interpret domestic law in a way that the law is consistent with the international instrument?

Before we go further, let us consider a theoretical aspect of this problem. There are two schools of thought, namely dualism and monism. ${ }^{21}$ According to monism, municipal law and international law belong to one and the same legal order. Here, international law reigns supreme even in the municipal sphere and over individuals in a State. If there is conflict between international law and municipal law, international law prevails. International law is regarded as the best mechanism to protect human rights.

According to dualism, municipal law and international law are separate legal systems. International law concerns relations between States. Municipal law on the other hand regulates the conduct of individuals and State within the State. If there is conflict between municipal law and international law on State matters, municipal law prevails. Thus, municipal courts apply municipal law and international courts apply international law.

An alternative approach to this dichotomy is offered by rejecting the idea that municipal law and international law have a common field of operation. ${ }^{22}$ According to this view, the two systems work in different planes, thus never come into conflict. Each is supreme within its own system. What may be in conflict is the obligation of a State to act in accordance with international law. If municipal law is inconsistent with international law, the municipal law remains valid but the State is obliged to fulfil its international responsibility in changing her municipal law. This approach is viewed as the practical approach in regulating municipal law and international law.

\footnotetext{
$21 \quad$ Ian Brownlie, Principles of Public International Law, Oxford: Clarendon Press, 1998, at 30.

22 Ian Brownlie, Principles of Public International Law, Oxford: Clarendon Press, 1998, at 33. See further Sir Gerald Fitzmaurice 92 Hague Recueil (1957, II), at 68-94.
} 


\section{ISSUES OF INTERNATIONAL LAW BEFORE MUNICIPAL COURTS}

Liability of States to act according to their international obligations will invite discussion about enforcement and execution of decisions of international tribunals. In the context of explaining the status of international law in the Malaysian legal system, this topic is outside the scope this article. The focus instead should be on issues of international laws before municipal courts. The issue is how municipal courts treat international law. For instance, if it is argued that Malaysian law on gender equality is inconsistent with the Convention on the Elimination of All Forms of Discrimination against Women (CEDAW), should the court replace the provision in Malaysian law in accordance with CEDAW requirements? In other words, when and how do municipal courts give effect to international law in the municipal sphere?

In this regard, we could consider two doctrines, namely the doctrine of incorporation and the doctrine of transformation. According to the doctrine of incorporation, customary rules of international law, are part of municipal law as long as they are not inconsistent with legislation. ${ }^{23}$ In this regard, municipal courts would first have to ascertain customary rules of international law or treaty provisions and then to determine whether the rules are not in conflict with municipal legislation.

Another doctrine that has gained currency is the doctrine of transformation. According to this doctrine, customary rules of international law or treaties are part of municipal law only in so far as the rules have been adopted by legislation. ${ }^{24}$ Thus, municipal courts cannot apply customary rules of international law or treaties without legislative process. The treatment of Malaysian courts will be examined below. The discussion will be divided into two; namely treatment of customary rules of international law and treatment of treaties.

23 Ian Brownlie, Principles of Public International Law, Oxford: Clarendon Press, 1998, at 42.

$24 \quad$ Regina v Keyn (1876) 2 Ex D 63, at 202-203; Ian Brownlie, Principles of Public International Law, Oxford: Clarendon Press, 1998, at 43. 


\section{CUSTOMARY RULES OF INTERNATIONAL LAW}

The Federal Constitution of Malaysia-proclaiming itself as the supreme law ${ }^{25}$ does not say anything about international law being a source of law. ${ }^{26}$ It does not mean however, that international law has no place in the constitutional scheme of things. The Federal Constitution provides that Parliament has the legislative power to make law with regard to treaties and matters of international law. ${ }^{27}$ The Federal Government, as opposed to the State Governments, has the power to enter into treaties. ${ }^{28}$ However, as a State in this globalised world, Malaysia may consider the doctrine of incorporation in applying customary rules of international law. ${ }^{29}$

Malaysian courts have applied customary rules of international law. A pre-Merdeka (pre-independence) court applied customary rules of international law with regard to the validity of orders of courts administered by the Japanese occupying authority in Malaya. ${ }^{30}$ The custom is to recognise judicial actions of the courts administered by the occupying forces. Similarly, actions of the occupying forces taking into custody property of its enemy are legitimate and should be recognised by the courts after the end of occupation. ${ }^{31}$

In other instances, the courts have acknowledged the relevance of customary rules of international law. However, in those instances, the courts did not find the existence of the customary rules to be proven. In Megat Ibrahim, the court entertained the idea that the power to banish

$25 \quad$ Article 4(1) of the Federal Constitution.

$26 \quad$ For a discussion on this see Heliliah bte Hj Yusof, "Internal Application of International Law in Malaysia and Singapore” (1969) 1 Singapore Law Review 62, at 69.

27 Article $74(1)$ reads together with the Federal List of the Federal Constitution.

28 Article 76 of the Federal Constitution. See also The Government of the State of Kelantan $v$ The Government of The Federation of Malaya and Tunku Abdul Rahman Putra Al-Haj [1963] MLJ 355.

29 Abdul Ghafur Hamid @ Khin Maung Sein, Public International Law: A Practical Approach, $2^{\text {nd }}$ Ed., Petaling Jaya: Pearson Prentice Hall, 2007, at 67.

$30 \quad$ Sockalingam Chettiar v Chan Moi (F) [1947] 1 MLJ 154.

31 Chop Sun Cheong Loong and Another v Lian Teck Trading Company [1947] 1 MLJ 119. 
a natural born subject of a Ruler of a State was unique. ${ }^{32}$ However, the court found that the party did not produce authority that such a power was contrary to international law.

The courts seem to accept the doctrine of incorporation of customary rules of international law where international law is applied directly by municipal courts. Although there is an opinion that in the previous cases of pre-independence, courts have applied the customary rules through English common law, ${ }^{33}$ such opinion has no clear basis from the judgments. It is arguable that the courts did refer to English courts cases, not as authorities to be followed under common law rules, but as evidence of customary rules of international law.

However, other cases - which incidentally are post-independence cases-did apply customary rules of international law through the application of English common law. In Village Holdings Sdn Bhd, the court considered the question of immunity of the sovereign of the Queen in Right of Canada. ${ }^{34}$ According to the court, the doctrine of absolute immunity is applicable in Malaysia since that was the law in England as at year 1956. ${ }^{35}$ According to the Civil Law Act 1956, that is the law applicable to Malaysia. ${ }^{36}$

It is unfortunate that the court had to rely on English common law to receive customary rules of international law. One reason for this

$32 \quad$ Megat Ibrahim $v$ The British Resident of Perak Superintendent, Convict Establishment, Taiping [1933] 2 MLJ 154.

33 Abdul Ghafur Hamid @ Khin Maung Sein, Public International Law: A Practical Approach, $2^{\text {nd }}$ Ed., Petaling Jaya: Pearson Prentice Hall, 2007, at 69; Abdul Ghafur Hamid @ Khin Maung Sein, "Judicial Application of International Law in Malaysia: A Critical Analysis” (2005) 34:2 INSAF 1, at 9. See also Tunku Sofiah Jewa, Public International Law: A Malaysian Perspective, Vol. I, Kuala Lumpur: Pacifica Publications, 1996, at 28.

$34 \quad$ Village Holdings Sdn Bhd v Her Majesty The Queen in Right of Canada [1988] 2 MLJ 656.

Village Holdings Sdn Bhd v Her Majesty The Queen in Right of Canada [1988] 2 MLJ 656, at 664, per Shankar J. But see Commonwealth of Australia v Midford (Malaysia) Sdn Bhd \& Anor [1990] 1 MLJ 475, SC where the Supreme Court accepted the doctrine of limited immunity.

$36 \quad$ Section 3 of the Civil Law Act 1956. See also Commonwealth of Australia v Midford (Malaysia) Sdn Bhd \& Anor [1990] 1 MLJ 475, SC. 
is the misunderstanding that the Civil Law Act 1956 purports "to state comprehensively the sources of law" which the Malaysian courts can refer to. ${ }^{37}$ Malaysia as an independent State should have its own indigenous jurisprudence in accepting or not accepting international law. Malaysia as a State belonging to the league of nations should not be subjected to a law of another State in determining whether to apply a particular international law. The courts may refer to decisions of other countries to elucidate whether a particular practice constitutes a customary rule. However, the courts should not relinquish responsibilities to others to make a considered decision.

The above point, on the failure of the courts to use or to develop indigenous jurisprudence in receiving international law should be emphasised. We should see all issues from our own perspective. This does not mean that we should not empathise with others or should not learn from experiences of others. Rather, the concern is not to blindly follow others without any effort to galvanise our own legal tradition. Thus, rather than using English common law as a basis of incorporating customary rules of international law, ${ }^{38}$ the open ended definition of "law" under the Federal Constitution should be construed to allow, subject to other provisions of the constitution, such incorporation. ${ }^{39}$

From preceding paragraphs, we have two methods of application of customary rules of international law by municipal courts. One,

$37 \quad$ Section 3 of the Civil Law Act 1956; HL Dickstein, "The Internal Application of International Law in Malaysia: A Model of the Relationship between International and Municipal Law" (1974) 1 JMCL 204, at 204. See also Farid Sufian Shuaib et al., Sumber UndangUndang Malaysia: Artikel Terpilih, Kuala Lumpur: Dewan Bahasa dan Pustaka, 2007, at 9-16.

38_Abdul Ghafur Hamid @ Khin Maung Sein, “Judicial Application of International Law in Malaysia: A Critical Analysis” (2005) 34:2 INSAF 1 , at 8-9.

39 Article 160 of the Federal Constitution defines law as "includes written law, the common law in so far as it is in operation in the Federation or any part thereof, and any custom or usage having the force of law in the Federation or any part thereof" (emphasis added). See also Abdul Aziz Bari, "Undang-Undang Antarabangsa: Asas, Pelaksanaan dan Masa Depannya” (2006) 18:3 KANUN 1, at 7-8; Mohd Hisham Mohd Kamal, "Perlembagaan Malaysia dalam Era Globalisasi," paper presented in Persidangan Undang-Undang Tuanku Ja'afar 2007, 21-22 August 2007, organised by Law Faculty, National University Malaysia, at 44. 
customary rules could be applied through the use of the doctrine of incorporation where customary rules are directly applied by municipal courts. Second, through an indirect route of English common law since the courts could refer to English common law (subject to question of cutoff dates) in the event of an apparent lacuna in Malaysian law. Under both methods, there is no requirement of legislative actions to transform international law into municipal law.

However, problems may arise if customary rules of international law are put into treaties. A treaty may establish new rules in international law or it may only put in no uncertain terms customary rules that are already in existence. It may only provide obligations between parties of the international agreement. ${ }^{40}$ We will see in the subsequent section that for treaties, the doctrine of transformation is generally used.

Lest we forget, municipal courts have to apply municipal laws. Thus, it is not the task of the courts to examine whether a particular legislation is consistent with international law. ${ }^{41}$ The duty of the courts is to apply the municipal law as they find it. However, in statutory interpretation, the presumption is that the legislature intends to respect the rules of international law. ${ }^{42}$ Thus, if the statute is interpreted to be capable of respecting the rules of international law, then such interpretation may be preferred.

\section{TREATY}

A treaty is any international written agreement called by any name (treaty, convention, protocol, charter or exchange notes) concluded between two or more States and governed by international law. ${ }^{43}$ In

$40 \quad$ DJ Harris, Cases and Material on International Law, $5^{\text {th }}$ Ed., London: Sweet \& Maxwell, 1998, at 45-46.

$41 \quad$ PP v Wah Ah Jee (1919) 2 FMSLR 193.

$42 \quad$ Faridah Begum Bte Abdullah v Sultan Haji Ahmad Shah Al Mustain Billah Ibni Almarhum Sultan Abu Bakar Ri'ayatuddin Al Mu'adzam Shah [1996] 1 MLJ 617, Special Court for Rulers, at 623. See article 2(1)(a) of the Vienna Convention on the Law of Treaties 1969. See less usual names of treaties such as "Text" and "Timetable" in Anthony Aust, Modern Treaty Law and Practice, $2^{\text {nd }}$ Ed., Cambridge: Cambridge University Press, 2007, at 28. 
order to bring a treaty into force, there must be ratification. Generally, ratification involves the act of the State and the formal exchange or deposit of the instrument of ratification by the State. The State here refers to the Federal Government of Malaysia. ${ }^{44}$ The formal exchange or deposit of the instrument shows the consent of the State to be bound by the treaty. However, at the end of the day, the consent of the State to be bound depends on the provision of the treaty and the intention of the parties. ${ }^{45}$ Thus, although a party did not sign a treaty, a State may accept its provision nonetheless. This, sometimes is referred to as "accession." 46

A State that ratifies a treaty may not accept all provisions of the treaty. A State may exclude some provisions of the treaty by "reservation." A reservation is a unilateral statement made by a State when ratifying a treaty that it wants to exclude certain provisions of the treaty in its application to that State. ${ }^{47}$ This flexibility promotes universality of acceptance of treaties at the expense of depth of obligations. Furthermore, it may not be practicable to insist on complete acceptance from every State. The limit of the reservation is that the reservation is compatible with the object and purpose of the Convention. ${ }^{48}$

Malaysia, for instance, ratified the Convention on the Prevention and Punishment of the Crime of Genocide in 1994. An example of a reservation made by Malaysia is on the Convention on the Convention

$44 \quad$ Reading together articles 39, 80 and 74. See also The Government of the State of Kelantan $v$ The Government of The Federation of Malaya and Tunku Abdul Rahman Putra Al-Haj [1963] MLJ 355.

45 Article 14 of the Vienna Convention on the Law of Treaties 1969.

$46 \quad$ Articles 15 and 16 of the Vienna Convention on the Law of Treaties 1969; Ian Brownlie, Principles of Public International Law, Oxford: Clarendon Press, 1998, at 612. Examples of treaties of which entered into accession are the Vienna Convention on Diplomatic Relations. See further Tunku Sofiah Jewa, Public International Law: A Malaysian Perspective, Vol. 1, Kuala Lumpur: Pacifica Publications, 1996, at 170217.

$47 \quad$ Article 19 of the Vienna Convention of the Law of Treaties 1969. Advisory opinion of the International Court of Justice in Reservations to Genocide Convention (1951) 15 ICJ Reports 15, at 21, 24. See further Ian Brownlie, Principles of Public International Law, Oxford: Clarendon Press, 1998, at 614. 
on the Elimination of All Forms of Discrimination against Women (CEDAW). It may be pointed out that a list of treaties and its status is available at the United Nation website. ${ }^{49}$ The Attorney General's Chambers, Malaysia website also provides helpful information. ${ }^{50}$

Ratification alone does not make the terms of the treaty applicable for municipal law. Here we have to distinguish between the obligation of the State in international law to be bound by the ratified treaties, and the ability of the domestic courts to apply the content of the treaties. The legislature needs to transform or incorporate the content of the treaty into domestic law by legislating the terms of the treaty or expressly adopting the treaty through relevant statutes. This is because the basic rule regarding treaties is that the treaties do not form part of domestic law and thus domestic courts cannot apply the treaties unless the legislature transform it into municipal law. ${ }^{51}$ For instance, Malaysia has enacted the Child Act 2001 to perform her obligation under the Convention on the Rights of the Child. ${ }^{52}$ The scheme in the Federal Constitution that Parliament has the competency to enact laws for the purpose of implementing any treaty seems to indicate that Malaysia adopts the doctrine of transformation. ${ }^{53}$

The requirement of transforming treaties provisions into municipal law can be seen in Narongne Sookpavit where a fishing boat manned by Thai fishermen was apprehended by the Malaysian Naval Patrol vessel in Malaysian waters. ${ }^{54}$ The fishermen among others, contended they

\begin{tabular}{ll}
\hline 49 & http://untreaty.un.org/ \\
50 & http://www.agc.gov.my \\
51 & Kok Wah Kuan v Pengarah Penjara Kajang, Selangor Darul Ehsan \\
& [2004] 5 MLJ 193, at 224; Dato’ Param Cumaraswamy v MBF Capital \\
& Bhd \& Anor [1997] 3 MLJ 824, at 848. See also J H Rayner (Mincing \\
& Lane) Ltd v Department of Trade \& Industry [1990] 2 AC 418, at 500. \\
& For cases on other international instruments, see Mohamad Ezam Bin \\
& Mohd Noor v Ketua Polis Negara \& Other [2002] 4 MLJ 449, FC, at \\
& 513-514; Merdeka University Bhd v Government of Malaysia [1981] 2 \\
& MLJ 356. \\
& See Kok Wah Kuan v Pengarah Penjara Kajang, Selangor Darul \\
& Ehsan [2004] 5 MLJ 193, at 217. \\
& Article 76(1)(a) of the Federal Constitution. See also Abdul Aziz Bari, \\
& "Undang-Undang Antarabangsa: Asas, Pelaksanaan dan Masa \\
& Depannya” (2006) 18:3 KANUN 1, at 8. \\
& Public Prosecutor v Narongne Sookpavit \& Ors [1987] 2 MLJ 100.
\end{tabular}


were heading to Singapore and there was no alternative route but to take the course they have taken. Thus, they claimed for peaceful passage or the right of innocent passage through Malaysian waters. The court declined to accept this claim because the Malaysian legislature did not transform the particular provision of the Convention of the Law of the Sea with regard to innocent passage into domestic law. Although arguably the right to peaceful passage-namely the right to navigate through the territorial sea of coastal State-exists in customary rules of international law of the sea, ${ }^{55}$ the action of the Malaysian legislature in not adopting that particular provision necessitates refusal of the municipal court to accept the same. ${ }^{56}$

Malaysia has ratified numerous treaties and has transformed them into legislation. In Orhan Olmez, ${ }^{57}$ the Supreme Court referred to the Vienna Convention on the Diplomatic Relations 1961 as transformed by the Diplomatic Privileges (Vienna Convention) Act $1966 .{ }^{58}$ Similarly in Regional Centre for Arbitration, ${ }^{59}$ the Court referred to the International Organisations (Privileges and Immunities) Act 1992; an Act transforming the Convention on the Privileges and Immunities of the United Nations 1946.

\section{CONSTITUTIONAL INTERPRETATION AND INTERNATIONAL LAW}

Malaysian courts have not discussed effects of treaties on fundamental liberties' provisions under the Federal Constitution. This is unlike in England for instance, where European Convention for the

$55 \quad$ See further article 14 of the Convention of Territorial Sea of 1958; article 19 of the Law of the Sea Convention 1982; Ian Brownlie, Principles of Public International Law, Oxford: Clarendon Press, 1998, at 191-193.

$56 \quad$ Emergency (Essential Powers) Ordinance No. 7 of 1969 (PU(A) 307A).

$57 \quad$ Public Prosecutor v Orhan Olmez [1988] 1 MLJ 13, SC.

$58 \quad$ Section 3 of the Diplomatic Privileges (Vienna Convention) Act 1966 (Revised 2004) provides that "the Articles set out in the Schedule (being Articles of the Vienna Convention on Diplomatic Relations signed in 1961) shall have the force of law in Malaysia."

$59 \quad$ Regional Centre for Arbitration v Ooi Beng Choo \& Anor (No 2) [1998] 7 MLJ 193. 
Protection of Human Rights and Fundamental Freedoms consistently comes into the picture in deliberating about human rights in England. However, the effect of the Universal Declaration of Human Rights (UDHR) looms large in Malaysian constitutional discourse. ${ }^{60}$

The Declaration is not a treaty. It is merely a pledge which is not legally binding by the States to promote human rights. ${ }^{61}$ It is a political document pressed through the General Assembly of the United Nations by "the West" by sheer number and influential figures. ${ }^{62}$ The Declaration "is merely a statement of principles devoid of any obligatory character." 63 However, the Declaration does promote human rights. The principles in the Declaration were translated into a binding instrument in the form of treaties, such as the Covenant on Civil and Political Rights. The fact that conventions have to be constructed apart from the Declaration further reflect the non-binding nature of the Declaration.

There were arguments that the courts should consider international instruments in interpreting the Federal Constitution. ${ }^{64}$ The Federal Court rejected this argument because international instrumentsby themselves - do not form part of municipal law. ${ }^{65}$ However, there are opinions that the courts should consider the Declaration in advancing the rights under the Federal Constitution. ${ }^{66}$ This is because the rule that

60 See for instance Shamrahayu A Aziz, “Apostasy and Religious Freedom: A Response to Thio Li-Ann” [2007] 2 MLJ i, at xiii.

61 Antonio Cassese, International Law, $2^{\text {nd }}$ Ed., Oxford: Oxford University Press, 2005, at 381; Abdul Ghafur Hamid @ Khin Maung Sein, Public International Law: A Practical Approach, $2^{\text {nd }}$ Ed., Petaling Jaya: Pearson Prentice Hall, 2007, at 348. Antonio Cassese, International Law, $2^{\text {nd }}$ Ed., Oxford: Oxford University Press, 2005, at 381. Merdeka University Berhad v Government of Malaysia [1981] 2 MLJ 356, at 366.

See Mohamad Ezam Bin Mohd Noor v Ketua Polis Negara \& Other [2002] 4 MLJ 449, FC, at 513-514. Mohamad Ezam Bin Mohd Noor v Ketua Polis Negara \& Other [2002] 4 MLJ 449, FC, per Siti Norma Yaakob FCJ, at 513-514. See also Merdeka University Berhad v Government of Malaysia [1981] 2 MLJ 356, at 366.

66 This opinion takes the cue from an appeal from Bahamas to the Privy Council in Higgs $v$ Minister of National Security [2000] 2 WLR 1368. 
excludes courts' reference to non-transformed treaties is to protect the subjects from actions of the executive, namely the action of consenting to a treaty. ${ }^{67}$ Thus, if the benefit of the non-incorporated treaties is to extend the protection of the people against the actions of the executive, no such rationale-namely the protection against actions of the executiveis applicable.

A problem with this argument is that the UDHR is not a treaty. Thus reference cannot be made to cases which consider the effect of treaties rather than the Universal Declaration of Human Rights as in Higgs where the relevant instrument is the American Convention on Human Rights 1969. ${ }^{68}$ The Declaration may become international law if it has transformed into international custom. This has to be established by looking at State practices and it has not yet transformed into one. ${ }^{69}$

Nevertheless, the judge in Abd Malek bin Hussin ${ }^{70}$ who regarded himself-as a judge-as the "protector of fundamental liberties," did allude to the universal value shared by the Federal Constitution and the Universal Declaration of Human Rights 1948. ${ }^{71}$ Although the Court did not discuss the relevance of the international instrument in municipal law, it could be said the Court had regard to it in safeguarding the rights of a detainee under the Internal Security Act 1960.

Moreover, the assertion that "regard shall be had to the Universal Declaration of Human Rights 1948"72 in the Human Rights Commission of Malaysia Act 1999 seems to indicate that the Universal Declaration of Human Rights may be used as a principal document to develop our

67 Higgs v Minister of National Security [2000] 2 WLR 1368, PC.

$68 \quad$ Higgs $v$ Minister of National Security [2000] 2 WLR 1368.

69 HO Agarwal, International Law \& Human Rights, $5^{\text {th }}$ Ed., Allahabad: Central Law Publication, 1999, at 657-658; Mohd Hisham Mohd Kamal, "Perlembagaan Malaysia dalam Era Globalisasi," paper presented in Persidangan Undang-Undang Tuanku Ja'afar 2007, 21-22 August 2007, organised by Law Faculty, National University Malaysia, at 5455.

$70 \quad$ Abd Malek bin Hussin v Borhan bin Hj Daud \& Ors [2008] 1 MLJ 368, per Mohd Hishamudin J, at 383.

71 Abd Malek bin Hussin v Borhan bin Hj Daud \& Ors [2008] 1 MLJ 368, at 383. See also Haw Tua Tau v Public Prosecutor [1981] 2 MLJ 49, PC. Section 4(4) of the Human Rights Commission of Malaysia Act, 1999 (Act 597) (Reprint 2001). 
constitutional guarantees of fundamental rights. ${ }^{73}$ However, although the Federal Constitution needs to be construed liberally, the language of the Constitution needs to be respected so that indigenous characters of the Constitution are maintained.

\section{DEVELOPMENT OF MALAYSIAN COMMON LAW}

Another way of applying international law is by using it to develop Malaysian common law. In this way, international law is not applied directly but is used to inform the courts in moulding the common law. Sagong Bin Tasi uses this approach in shaping Malaysian common law to recognise the proprietary rights of the aborigines (Orang Asli) over their customary and ancestral lands. ${ }^{74}$ The Court seems to agree with the observation of the Australian High Court that although common law need not necessarily conform to international law, international law can be a great influence in setting the course for the development of common law. ${ }^{75}$

\section{INTERNATIONAL TRIBUNALS AND MUNICIPAL COURTS}

What we have considered in the above paragraphs is the approach of the Malaysian courts with regard to international law as a source of law in deciding disputes before the courts. It is pertinent to note that the three organs of government, namely the legislature, executive and the judiciary, have their own roles in interacting with international institutions, obligations and laws. ${ }^{76}$

$73 \quad$ See Mersing Omnibus Co Sdn Bhd v Kesatuan Pekerja-Pekerja Pengangkutan Semenanjung Malaysia \& Anor [1999] 1 MLJ 44, at 48, interpreting "shall have regard" in the Industrial Relations Act 1967 to be a phrase imposing an obligation.

$74 \quad$ Sagong Bin Tasi \& Ors v Kerajaan Negeri Selangor \& Ors [2002] 2 MLJ 591, at 615.

$75 \quad$ Mabo v Queensland (No 2) (1992) 175 CLR 1, per Brennan J.

76 See further Abdul Aziz Bari \& Farid Sufian Shuaib, Constitution of Malaysia: Text and Commentary, $2^{\text {nd }}$ Ed., Petaling Jaya: Pearson Prentice Hall, 2006, $3^{\text {rd }}$ Print 2007, at 79-81. 
The executive is the authority in interacting with other States and international institutions. The executive authority of the Federation of Malaysia, namely the Federal Government, has the power to enter into treaties. ${ }^{77}$ Although Parliament has the power to legislate on treaties, ${ }^{78}$ in the Westminster system of government, where the executive most of the time reigns over the legislature, the Cabinet as the inner sanctum of the Federal Government, has great influence over the law-making process in Parliament. ${ }^{79}$

The courts, we have seen, apply international law either directly or through municipal legislation. The court, in one instance, seemed somewhat ambivalent in applying a decision of the International Court of Justice. During the season of mega damages for libel actions-the plaintiffs each claimed for RM15,000,000.00-a special rapporteur on the independence of judges and lawyers of the United Nations Commission on Human Rights was sued for defamation for his comment to the press regarding alleged corruption in the judiciary. ${ }^{80}$ In Dato' Param Cumaraswamy ${ }^{81}$ the defendant claimed immunity based on his status as the special rapporteur of the Human Rights Commission. The Court of Appeal upheld a decision of the High Court not to dismiss the case summarily and to defer the question of immunity at the full trial despite the existence of a certificate from the Secretary-General of the United Nation stating that the defendant had acted within his mandate. ${ }^{82}$

Separately, the Secretary-General of the United Nations initiated a reference to the International Court of Justice for an advisory opinion regarding the failure of the Government of Malaysia to include, in the

$77 \quad$ Reading together articles 39, 80 and 74 of the Federal Constitution. See also The Government of The State of Kelantan $v$ The Government of The Federation of Malaya and Tunku Abdul Rahman Putra Al-Haj [1963] MLJ 355.

78 Article 74 of the Federal Constitution.

79 See further Abdul Aziz Bari, Malaysian Constitution: A Critical Introduction, Kuala Lumpur: The Other Press, 2003.

$80 \quad$ MBF Capital Bhd \& Anor v Dato' Param Cumaraswamy[1997] 3 MLJ 300.

$81 \quad$ MBF Capital Bhd \& Anor v Dato’ Param Cumaraswamy[1997] 3 MLJ 300.

82 Dato' Param Cumaraswamy v MBF Capital Bhd \& Anor [1997] 3 MLJ 824, CA. 
Minister's certificate, the finding of the Secretary-General that the special rapporteur had acted within his mandate and the failure of the Malaysian court-as an organ of the State-to provide immunity to the special rapporteur. ${ }^{83}$ Furthermore, the special rapporteur was awarded costs against him for the amount of RM550,000.00 by the municipal court. The International Court of Justice opined that the Government of Malaysia was obliged to ensure that the special rapporteur enjoyed his immunity.

The International Court of Justice recognised that the executive and an independent judiciary are distinct organs. Nevertheless, a Staterepresented in its international relation by the executive organ-is obliged to use all means available to ensure that their obligations are met. The Court continuously emphasised the obligation and method of applying the obligation by Malaysia. ${ }^{84}$

This approach is perhaps explained by the surreal tenacity of the Malaysian courts during that time, to decide and to punish the dissenter and blasphemer of the proclaimed independence of the judiciary, and the uncorrupted state of the judiciary and public figures. ${ }^{85}$ Nevertheless, the Malaysian Court did grudgingly give effect to the opinion and set aside the case against the special rapporteur. ${ }^{86}$

$83 \quad$ Difference Relating to Immunity from Legal Process of a Special Rapporteur of the Commission on Human Rights (1999) ICJ 62. For a comment on this case see for instance Rosemary Rayfuse, "Immunities of United Nations Human Rights Special Rapporteurs: Who Decides?” (2001) 7:1 AJHR 169; A Duxbury, “The Privileges and Immunities of United Nations' Experts: The Cumaraswamy Case” (2000) 1:2 Asia Pacific Journal on Human Rights and the Law 88. On domestic autonomy of municipal courts, see Ian Brownlie, Principles of Public International Law, Oxford: Clarendon Press, 1998, at 51-52; Githathevi Kanisin, "The Difference Relating to Immunity from Legal Process of a Special Rapporteur of the Commission on Human Rights - A Case Review of the International Court of Justice Advisory Opinion” [1999] 4 MLJ cxiii. Jeopardy: Malaysia 2000, <http://www.ibanet.org>. 


\section{CONCLUDING REMARKS}

The increased interaction between nations and between individuals of different nations necessitate that more emphasis be given to international law. This in general has been recognised by relevant government agencies and law schools.

Nevertheless, giving importance to international law does not mean different nations with different cultures and religions should have uniform law. It is a tempting assumption that with uniform law we will have less conflict. ${ }^{87}$ This assumption excluded has the possibility that global uniformity may be repressive because it may be produced by sheer force of the elite.

The Malaysian courts have not embraced monism in the treatment of international instruments, which is rightly so. ${ }^{88}$ Although human rights instruments in particular may serve as a vehicle to protect fundamental liberties of mankind in every part of the world, ${ }^{89}$ it should not be a vehicle to trample particularities and peculiarities of a nation's legal culture and tradition. ${ }^{90}$

Thus, when CEDAW speaks of the same rights and responsibilities during marriage as at its dissolution for instance, ${ }^{91}$ a nation

87 Werner Menski, Comparative Law in a Global Context: The Legal System of Asia and Africa, $2^{\text {nd }}$ Ed., Cambridge: Cambridge University Press, 2006, at 3.

88 See for instance Lina Joy v Majlis Agama Islam Wilayah Persekutuan dan lain-lain [2007] 4 MLJ 585, FC; Kamariah Bte Ali dan Lain-Lain $v$ Kerajaan Negeri Kelantan dan Satu Lagi [2005] 1 MLJ 197, FC; Merdeka University Bhd v Government of Malaysia [1981] 2 MLJ 356. But see the anxiety for some in the United States of America in Melissa A Waters, "Creeping Monism: The Judicial Trend toward Interpretive Incorporation of Human Rights Treaties” (2007) 107 Colum L Rev 628.

89 See for instance the success, or lack thereof, of international instruments and institutions in preventing genocide in John B Quigley, The Genocide Convention: An International Law Analysis, Aldershot: Ashgate Publication, 2006.

$90 \quad$ On legal culture and legal tradition respectively, see for instance Kirsten Hastrup (Ed.), Legal Cultures and Human Rights: The Challenge of Diversity, Boston: Kluwer Law International, 2001; H Patrick Glenn, Legal Traditions of the World, $2^{\text {nd }}$ Ed., Oxford: Oxford University Press, 2004.

$91 \quad$ Article 16(c) of the Convention on the Elimination of All Forms of Discrimination against Women (CEDAW). 
with its own legal culture which does not equate sameness with equality has rightly made relevant reservations. ${ }^{92}$ Nevertheless, others in legal discourse have chosen to regard international instruments as supreme; a creeping monism in the making. ${ }^{93}$ Alas, in making this observation, one may be misled in thinking that provisions of a convention are necessarily international law, which is far from the truth. The provisions are merely contractual terms producing obligations on States. ${ }^{94}$

$92 \quad$ See for instance Zaleha Kamarudin, "Harmonising the International Human Rights Law with the Rights of Women," in Syed Arabi Idid (Ed.), Malaysia at 50: Achievements and Aspirations, Singapore: IIUM and Thomson, 2008.

93 See for instance National Council for Women's Organisations, "The Concluding Comments from the Committee for the Convention on the Elimination of All Forms of Discrimination against Women (CEDAW) to the Ministry of Women, Family and Community Development, Malaysia," 8 $8^{\text {th }}$ March 2007.

94 DJ Harris, Cases and Material on International Law, $5^{\text {th }}$ Ed., London: Sweet \& Maxwell, 1998, at 45-46. But see for instance Sally Engle Merry, "Constructing a Global Law-Violence against Women and the Human Rights System” (2003) 28 Law and Social Inquiry 941. 